Eur. J. Mineral.

2009, 21, 649-661

Published online April 2009

HP-HT mineral physics:

implication for geosciences

\title{
Dynamic effects of aseismic ridge subduction: numerical modelling
}

\author{
TARAS V. GERYA ${ }^{1,2, *}$, DAVID FOSSATI ${ }^{1}$, CURDIN CANTIENI ${ }^{1}$ and DIANE SEWARD ${ }^{1}$ \\ ${ }^{1}$ Department of Geosciences, Swiss Federal Institute of Technology (ETH - Zürich), CH-8092 Zurich, Switzerland \\ *Corresponding author, e-mail: taras.gerya@erdw.ethz.ch \\ ${ }^{2}$ Adjunct Professor of Geology Department, Moscow State University, 119899 Moscow, Russia
}

\begin{abstract}
The subduction of oceanic aseismic ridges, oceanic plateaus and seamount chains is a common process that takes place in a variety of tectonic settings and seems to coincide spatially and temporally with a gap of volcanic activity, shallow or even horizontal slab angles, enhanced seismic activity and various topographic features. In the present study we focus on these dynamic effects on the basis of $2 \mathrm{D}$ thermomechanical modelling incorporating effects of slab dehydration, mantle-wedge melting and surface topography development. In order to ascertain the impact of a moderate-size $(200 \times 18 \mathrm{~km})$ aseismic ridge, 12 pairs of experiments (one for the case with a ridge, the other without) were carried out varying slab density and subducting- and overriding-plate velocities. By analysing pairs of experiments we conclude that subduction of a moderate-sized ridge does not typically result in strong slab flattening and related decrease of magmatic activity. This, in turn, suggests that, when slab flattening is indeed associated with the ridge subduction in nature, the slab itself should be in a nearly critical (i.e., transient from inclined to flat) state so that any local addition of positive buoyancy may strongly affect overall slab dynamics. Therefore, subducting ridges may serve as indicators of transient slab states in nature. Another important result from our study is the numerical quantification of strongly decreased magma production associated with flat slabs that may explain gaps in recent active volcanism at low-angle subduction margins. Lowering of magmatic rock production is caused by the absence of a hot mantle wedge above the flat slabs and does not directly depend on the mechanism responsible for the triggering of slab flattening. Finally we document several very distinct surface effects associated with the moderate-size ridge subduction such as local increase in elevation of overriding margin, enhancement of subduction erosion and landward trench displacement. Surface uplift may exceed the original ridge height due to additional uplift resulting from the overriding plate shortening. Topographic perturbations within the accretionary wedge domain are transient and have a tendency to relax after the ridge passes the trench. In contrast, the topographic high created in the continental portion of the overriding plate relaxes more slowly and may even be sustained for several millions of year after the ridge subduction.
\end{abstract}

Key-words: numerical modelling, ridge subduction, continental margin topography, magmatic activity.

\section{Introduction}

The subduction of oceanic aseismic ridges, oceanic plateaus and seamount chains is a common process that takes place in a variety of tectonic settings worldwide (e.g., McGeary et al., 1985; van Hunen et al., 2002; Espurt et al., 2008 and references therein). This process appears to coincide spatially and temporally with the gap of volcanism, shallow or even horizontal slab angles, enhanced seismic activity and various topographic effects (e.g., McGeary et al., 1985; van Hunen et al., 2002; Espurt et al., 2008 and references therein). For example, gaps in recent active volcanism at low-angle subduction below Peru, Central Chile and at the Nankai trough near Japan may apparently be related to the subduction of the Nazca Ridge, Juan Fernandez seamount chain and Palau-Kyushu Ridge, respectively (Cross \& Pilger, 1982; McGeary et al., 1985). Further, flat subduction occurs at about $10 \%$ of the modern convergent margins where there is a correlation with a subducting plateau or aseismic ridge (Gutscher et al., 2000). The absence of volcanism is explained by the disappearance of the hot mantle wedge with a decreasing dip angle of the slab: absence of the contact of the hydrated subducted crust with the overlying hot asthenosphere precludes partial melting and associated volcanism.

Several numerical studies have already been completed on the Pacific-type active margins (e.g., Sobolev \& Babeyko, 2005; Gerya \& Stoeckhert, 2006; Gorczyk et al., 2007a) and associated flat subduction (e.g., Van Hunen et al., 2000, 2002, 2004). In particular van Hunen et al. (2002) systematically analysed the role of subduction of oceanic plateaus in relation to the development of shallow flat subduction and concluded that: (i) metastability of the basaltic crust in the eclogite stability field is of crucial importance to maintain the plate buoyant sufficiently long to produce a flat-slab segment; (ii) the maximum yield stress in the slab must be limited to about $600 \mathrm{MPa}$ to allow for the necessary bending towards the horizontal; (iii) young slabs 
reveal flat subduction for larger parameter ranges than old slabs, since they are gravitationally more stable and show less resistance against bending; (iv) hydrous weakening of the mantle wedge area and lowermost continent are required to allow for the necessary deformation of a change in subduction style from steep to flat; (v) the maximum flat slab extent is about $300 \mathrm{~km}$ so that additional mechanisms, such as active overthrusting by an overriding continental plate (e.g., van Hunen et al., 2000), need to be invoked to explain the flat slab segments up to $500 \mathrm{~km}$ long below Peru and Central Chile.

The complexity of slab response to the ridge subduction was recently confirmed by analogue experiments of Martinod et al. (2005) who demonstrated that simple local (1D) isostatic considerations are not appropriate to predict slab behaviour during the subduction of a buoyant ridge perpendicular to the trench, because the rigidity of the plate forces the ridge to subduct with the dense oceanic lithosphere. On the other hand, oceanic ridges parallel to the trench have a stronger effect on the process of subduction because they simultaneously affect a longer trench segment (Martinod et al., 2005). Results of Martinod et al. (2005) were complemented by the systematic analogue study of Espurt et al. (2008) who demonstrated that flat subduction only occurs if a large portion of a buoyant slab segment is forced into subduction by kinematic boundary conditions, part of the buoyant plateau being incorporated into the steep part of the slab to balance the negative buoyancy of the dense oceanic slab. It has been shown (Espurt et al., 2008) that slab flattening is a long-term process $(\sim 10 \mathrm{Ma})$, which requires the subduction of hundreds of kilometres of buoyant plateau. Espurt et al. (2008) also analysed the overriding-plate shortening rate which increases if the oceanic plateau is large enough to decrease the slab pull effect. Slab flattening increases the interplate friction force and results in migration of the shortening zone within the interior of the overriding plate. The increase of the overriding plate topography close to the trench results from (1) the buoyancy of the plate subducting at the trench and (2) the shortening of the overriding plate. In addition to the above-mentioned large-scale analogue models including entire slabs, Hampel et al. (2004a) studied in 3D details of topographic development during relatively shallow stages of oblique ridge subduction with the use of sandbox experiments. It was shown that during oblique convergence the rigid model ridge caused a wave of uplift followed by subsidence shifting along the trench within the forearc. The modelled amount of uplift and uplift rates $(\sim 1.2 \mathrm{~km}$ and $0.9 \mathrm{~km} / \mathrm{Myr}$, respectively) agree well with the natural record at Peruvian forearc.

Despite the recent progress in both numerical and analogue modelling of ridge subduction, possible magmatic consequences of this process are not yet systematically modelled and the topographic response of the upper plate has been studied in detail only for a limited range of parameters corresponding to rather shallow subduction conditions (Hampel et al., 2004a). In the present paper we try to address these dynamic effects on the basis of $2 \mathrm{D}$ thermomechanical modelling incorporating effects of slab dehydration, mantle wedge melting and surface topography development. Compared to other studies dealing with similar computer models, our model's particular assets are (i) the use of an internal free erosion/sedimentation surface allowing one to analyse the topographic effects of various ridge subduction scenarios and (ii) treatment of water as an additional compositional phase which allows the analysis of the development of hydration and melting structures produced by water released from subducted oceanic crust. We are able, therefore, to study topographic and magmatic consequences of ridge subduction in a self-consistent way. Many of our experiments are geared towards the South American subduction zone (i.e., plate speeds and ages, ridge size, etc.) that facilitates comparison of our numerical results with available observations.

\section{Model setup}

\subsection{Initial model configuration}

In the present study we have used a recent 2D model of an active Pacific-type margin including free slab bending, propagation of water released from the subducting slab and partial melting ( $c f$. ., Gorczyk et al., 2007a for details). The model box is $2700 \mathrm{~km}$ long and $200 \mathrm{~km}$ deep and the initial geometry of the model (Fig. 1) corresponds to the onset of subduction at a passive continental margin (Regenauer-Lieb et al., 2001). In this model, oceanic crust consists of a $2 \mathrm{~km}$ thick sequence of hydrothermally altered basalts (metabasalts), and a $5 \mathrm{~km}$ section comprised largely of gabbroic rocks. A $1 \mathrm{~km}$ thick layer of serpentinized mantle is present at the base of the oceanic crust, as partial serpentinization of the oceanic slab mantle has been documented and modelled numerically (Rupke et al., 2004; Faccenda et al., 2008). The continental crust is $30 \mathrm{~km}$ thick and consists of upper and lower crustal layers of differing densities. Physical properties for all rocks involved in numerical simulation are given in Table 1.

The moderate-size $200 \mathrm{~km}$ wide and $18 \mathrm{~km}$ thick aseismic ridge composed of gabbroic rocks is defined on the oceanic plate at $250 \mathrm{~km}$ distance from the trench. In order to isolate the dynamic effects of ridge subduction, paired numerical experiments with similar parameters differing only by the presence/absence of the ridge were run in parallel. We used a rather moderate width of the ridge approximately corresponding to that of the Nazca ridge in the direction orthogonal to the trench (e.g., Hampel et al., 2004b).

The initiation of the subduction area is imposed by a $15 \mathrm{~km}$ thick and down to $42 \mathrm{~km}$ deep (below the bottom of the crust) initial zone of weakness (Fig. 1) starting below a basin filled with sediments (Regenauer-Lieb et al., 2001). In view of the possible role of water in the initiation of subduction (Regenauer-Lieb et al., 2001) this weak layer is represented as a brittle/plastic fault within mantle rocks, characterized by wet olivine rheology, and a high porefluid pressure. 


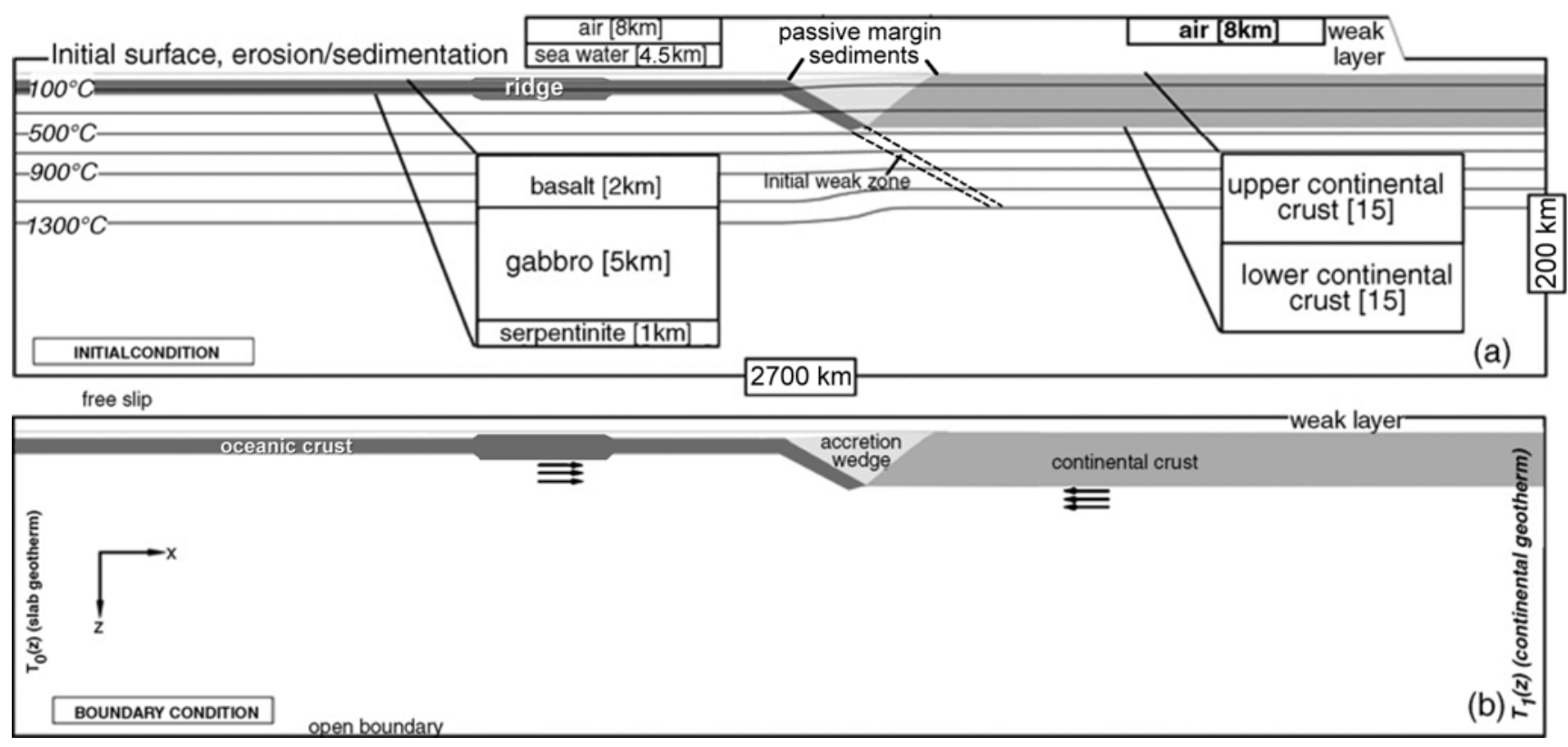

Fig. 1. Numerical model setup. Staggered grid resolution: $431 \times 101$ nodes, 2 million randomly distributed markers. Grid steps vary from $2 \times 2 \mathrm{~km}$ in the $400 \mathrm{~km}$ wide subduction area to $10 \times 2 \mathrm{~km}$ outside of this area.

Table 1. Material properties ${ }^{\mathrm{a}}$ used in the 2D numerical experiments.

\begin{tabular}{|c|c|c|c|c|c|}
\hline Rock type & $\rho_{o}, \mathrm{~kg} / \mathrm{m}^{3}$ & $k^{\mathrm{b}}, \mathrm{W} /(\mathrm{m} \mathrm{K})$ & Flow law ${ }^{c}$ & $C, \mathrm{MPa}$ & $\sin \phi$ \\
\hline Upper continental crust & 2700 (solid) 2400 (molten) & $0.64+807 /\left(T_{\mathrm{K}}+77\right)$ & Wet quartzite & 3 & 0.15 \\
\hline Upper oceanic crust (basalt) & 3000 (solid) 2900 (molten) & $1.18+474 /\left(T_{\mathrm{K}}+77\right)$ & Wet quartzite & 3 & 0 \\
\hline Lower oceanic crust (gabbro) & 3000 (solid) 2900 (molten) & $1.18+474 /\left(T_{\mathrm{K}}+77\right)$ & Plagioclase $\mathrm{An}_{75}$ & 3 & 0.15 \\
\hline Asthenospheric mantle & 3300 & $0.73+1293 /\left(T_{\mathrm{K}}+77\right)$ & Dry olivine & 3 & 0.6 \\
\hline Hydrated mantle & 3200 (solid) 2400 (molten) & $0.73+1293 /\left(T_{\mathrm{K}}+77\right)$ & Wet olivine & 3 & 0 \\
\hline
\end{tabular}

Material properties $-{ }^{\mathrm{a}} \mathrm{Cp}=1000 \mathrm{~J} \mathrm{~kg}^{-1} \mathrm{~K}^{-1}, \alpha=3 \times 10^{-5} \mathrm{~K}^{-1}, \beta=1 \times 10^{-5} \mathrm{MPa}^{-1}$. ${ }^{\mathrm{b}}$ Thermal conductivity is from Clauser \& Huenges (1995). ${ }^{\mathrm{c}}$ Flow laws are from Ranalli (1995). $\rho_{o}$ is the density at $\mathrm{T}=298 \mathrm{~K}$ and $\mathrm{P}=0.1 \mathrm{MPa}, k$ is thermal conductivity, $C$ is cohesion, $\phi$ is internal friction angle.

The initial temperature field in the oceanic plate is defined by an oceanic geotherm (Turcotte \& Schubert, 2002) for a $40 \mathrm{Myr}$ lithospheric cooling age. Within the first $72 \mathrm{~km}$ depth of the continental plate the initial temperature field is given as a linear increase from $0^{\circ}$ to $1367{ }^{\circ} \mathrm{C}$; from $72 \mathrm{~km}$ depth on, in the asthenospheric mantle, a gradient of $0.5^{\circ} \mathrm{C} / \mathrm{km}$ prevails.

\subsection{Boundary conditions}

The velocity boundary conditions are free slip at all boundaries except the lower boundary of the box, which is permeable in vertical direction (Gorczyk et al., 2007a). An infinite-like external free slip condition $\left(\partial v_{x} / \partial z=0\right.$, $\partial v_{z} / \partial z=v_{z} / \Delta z_{\text {external }}$, where $v_{x}$ and $v_{z}$ are, respectively, horizontal and vertical velocity components) along the bottom implies that free slip condition $\left(\partial v_{x} / \partial z=0\right.$, $v_{z}=0$ ) is satisfied at an external boundary located at a certain depth $\Delta z_{\text {external }}$ below the actual lower boundary of the model $\left(\Delta z_{\text {external }}=2000 \mathrm{~km}\right.$ for the present study). Similar to the usual free slip condition, external free slip allows global conservation of mass in the computational domain. In order to minimize mechanical interaction of cold slabs with the permeable lower boundary, the maximal viscosity at $10 \mathrm{~km}$ deep region along this boundary was limited to $10^{19} \mathrm{~Pa}$ s. Plate motions are prescribed locally in two regions by imposing constant horizontal velocities for the oceanic (at $x=1000 \mathrm{~km}$ ) and the continental (at $x=2000 \mathrm{~km}$ ) plates. Not prescribing the angle of subduction and velocity along the whole length of the slab allows for spontaneous slab bending below the trench area. In this case the dip angle of the subducting plate is mainly controlled by slab rheology and density as well as interaction 
with the surrounding mantle. We used a moderate value of $1 \mathrm{~cm} /$ year for an effective upward water percolation velocity from the slab that defines the dynamics of mantle wedge hydration in our model (Gorczyk et al., 2007a).

\subsection{Governing equations and numerical implementation}

The momentum, continuity, and heat conservation equations for the two-dimensional creeping-flow, accounting for thermal and chemical buoyancy, are solved using the modified I2VIS code (Gerya \& Yuen, 2003) based on conservative finite differences and a nondiffusive-markerin-cell technique. The conservation of mass is approximated by the incompressible continuity equation:

$\frac{\partial v_{x}}{\partial x}+\frac{\partial v_{z}}{\partial z}=0$

The 2D Stokes equations take the form:

$\frac{\partial \sigma_{x x}}{\partial x}+\frac{\partial \sigma_{x z}}{\partial z}=\frac{\partial P}{\partial x}$
$\frac{\partial \sigma_{z z}}{\partial z}+\frac{\partial \sigma_{x z}}{\partial x}=\frac{\partial P}{\partial z}-g \rho(T, P, C, M)$

The density $\rho(T, P, C, M)$ depends explicitly (Table 1$)$ on the temperature $(T)$, the pressure $(P)$, the composition $(C)$, and the melt fraction $(M)$ (Gerya \& Burg, 2007).

The heat conservation equation is formulated as (Gerya \& Yuen, 2003)

$\rho C_{p}\left(\frac{D T}{D t}\right)=-\frac{\partial q_{x}}{\partial x}-\frac{\partial q_{z}}{\partial z}+H_{r}+H_{a}+H_{S}+H_{L}$

$q_{x}=-k(T, C) \frac{\partial T}{\partial x} \quad q_{z}=-k(T, C) \frac{\partial T}{\partial z}$

$H_{a}=T \alpha \frac{D P}{D t} \quad H_{S}=\sigma_{x x} \dot{\varepsilon}_{x x}+\sigma_{z z} \dot{\varepsilon}_{z z}+2 \sigma_{x z} \dot{\varepsilon}_{x z}$

where $D / D t$ is the substantive time derivative; $x$ and $z$ denote, respectively, the horizontal and vertical coordinates; $\sigma_{x x}, \sigma_{x z}, \sigma_{z z}$ are components of the deviatoric stress tensor; $\dot{\varepsilon}_{x x}, \dot{\varepsilon}_{x z}, \dot{\varepsilon}_{z z}$ are components of the strain rate tensor; $P$ is pressure; $T$ is temperature; $q_{x}$ and $q_{z}$ are heat fluxes; $\rho$ is density; $g$ is the gravitational acceleration; $k(T, C)$ is the thermal conductivity, a function of composition and temperature (Table 1); $C_{p}$ is the isobaric heat capacity; $H_{r}, H_{a}, H_{s}$, and $H_{L}$ denote, the radioactive, adiabatic, shear and latent heat production, respectively. Other details of the numerical modelling approach used in this study including topographic evolution and water transport are described in details by Gorczyk et al. (2007a).

\section{Results}

\subsection{General development}

As found in previous studies (e.g., Van Hunen et al., 2000, 2002; Sobolev \& Babeyko, 2005; Gorczyk et al., 2007a, b) subduction dynamics varies significantly depending on the choice of parameters such as the density of subducted lithosphere, velocities of the plates and slab dehydration intensity. In order to ascertain the impact of an aseismic ridge, 12 pairs of experiments (one for the case with a ridge, the other without) were carried out varying slab density and subducting- and overriding-plate velocities (Table 2). The experiments were conducted with I2VIS code (Gerya \& Yuen, 2003) on Brutus computer cluster of ETH-Zurich. The names of the paired experiments are self explanatory (e.g., ria333300m, ria333300o): the first digit (3) stands for the velocity (in $\mathrm{cm} / \mathrm{y}$ ) of the subducting oceanic plate coming from the left; the second digit (3) for the velocity of the overriding continental plate coming from the right; the next four digits (3300) stand for the density (in $\mathrm{kg} / \mathrm{m}^{3}$ ) of the subducting oceanic mantle lithosphere at standard conditions ( $T=273 \mathrm{~K}$ and $P=1 \mathrm{bar}$ ); the letter at the end specifies whether the ridge is present (m) or absent (o) in the model.

Figure 2 shows the evolution of two reference models differing by only the presence/absence of a ridge. Both

Table 2. Parameters of conducted numerical experiments.

\begin{tabular}{|c|c|c|c|c|c|}
\hline Run & $\begin{array}{l}\text { Ridge } \\
\text { present }\end{array}$ & $\begin{array}{l}\text { Slab } \\
\text { density, } \\
\mathrm{kg} / \mathrm{m}^{3}\end{array}$ & $\begin{array}{c}\text { Subducting } \\
\text { plate } \\
\text { velocity, } \\
\mathrm{cm} / \text { year }\end{array}$ & $\begin{array}{l}\text { Overriding } \\
\text { plate } \\
\text { velocity, } \\
\mathrm{cm} / \text { year }\end{array}$ & $\begin{array}{c}\text { Convergence } \\
\text { rate, } \\
\text { cm/year }\end{array}$ \\
\hline \multicolumn{6}{|c|}{ Variable slab density } \\
\hline ria333100m & Yes & 3100 & 3 & 3 & 6 \\
\hline ria333100o & No & 3100 & 3 & 3 & 6 \\
\hline ria333150m & Yes & 3150 & 3 & 3 & 6 \\
\hline ria333150o & No & 3150 & 3 & 3 & 6 \\
\hline ria $333200 \mathrm{~m}$ & Yes & 3200 & 3 & 3 & 6 \\
\hline ria333200o & No & 3200 & 3 & 3 & 6 \\
\hline ria333250m & Yes & 3250 & 3 & 3 & 6 \\
\hline ria333250o & No & 3250 & 3 & 3 & 6 \\
\hline ria333300m & Yes & 3300 & 3 & 3 & 6 \\
\hline ria333300o & No & 3300 & 3 & 3 & 6 \\
\hline ria333350m & Yes & 3350 & 3 & 3 & 6 \\
\hline ria333350o & No & 3350 & 3 & 3 & 6 \\
\hline ria333400m & Yes & 3400 & 3 & 3 & 6 \\
\hline ria333400o & No & 3400 & 3 & 3 & 6 \\
\hline \multicolumn{6}{|c|}{ Variable plate velocities } \\
\hline ria243300m & Yes & 3300 & 2 & 4 & 6 \\
\hline ria243300o & No & 3300 & 2 & 4 & 6 \\
\hline ria423300m & Yes & 3300 & 4 & 2 & 6 \\
\hline ria423300o & No & 3300 & 4 & 2 & 6 \\
\hline \multicolumn{6}{|c|}{ Variable convergence rate } \\
\hline ria223300m & Yes & 3300 & 2 & 2 & 4 \\
\hline ria223300o & No & 3300 & 2 & 2 & 4 \\
\hline ria443300m & Yes & 3300 & 4 & 4 & 8 \\
\hline ria443300o & No & 3300 & 4 & 4 & 8 \\
\hline ria553300m & Yes & 3300 & 5 & 5 & 10 \\
\hline ria553300o & No & 3300 & 5 & 5 & 10 \\
\hline
\end{tabular}



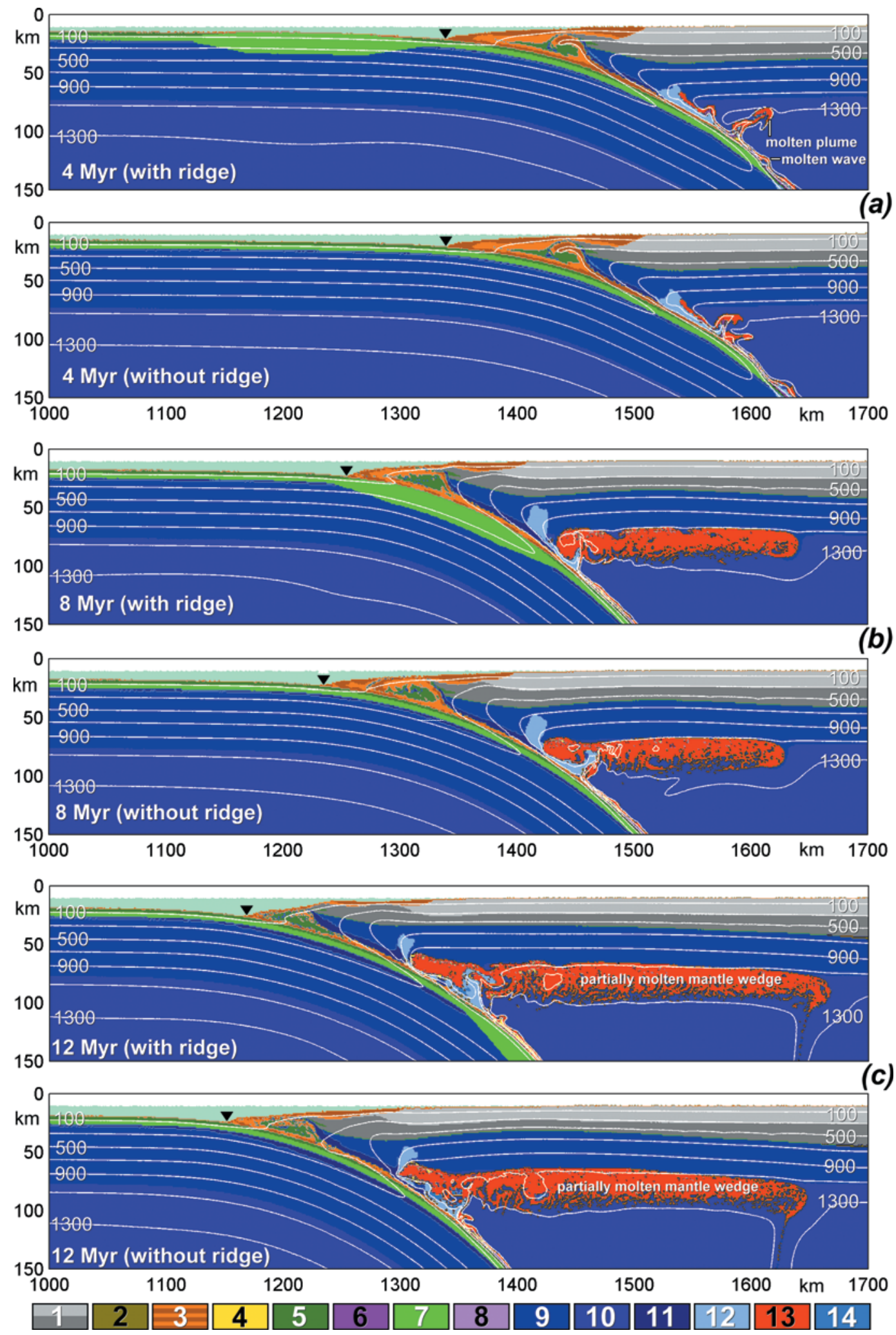

Fig. 2. Development of the reference models with and without a ridge (models ria333300m and ria333300o in Table 2). Colour code: 1, $2=$ continental crust $(1=$ solid, $2=$ partially molten); $3,4=$ sediments $(3=$ solid, $4=$ partially molten $) ; 5,6=$ upper $($ basaltic $)$ oceanic crust $(5=$ solid, $6=$ partially molten $) ; 7,8=$ lower (gabbroic) oceanic crust $(7=$ solid, $8=$ partially molten); $9,10=$ dry mantle $(9=$ lithospheric, $10=$ asthenospheric); $11,12,13,14=$ hydrated mantle $(11=$ serpentinized, $12=$ serpentine-free, $13=$ partially molten, 14 = quenched after melting). Some rocks (colours) are not present in this figure but can be found in other models. White lines represent isotherms in ${ }^{\circ} \mathrm{C}$. Black triangles show trench positions. 4, 8, $12 \mathrm{Myr}$ are model times. Large molten (red) areas in the mantle wedge in (b) and (c) are formed from multiple plumes (a) rising from the slab (Gorczyk et al., 2007b). 
models have a subducting- and overriding-plate velocity of $3 \mathrm{~cm} / \mathrm{y}$ and a standard lithospheric mantle density of $3300 \mathrm{~kg} / \mathrm{m}^{3}$. From the frames of Fig. 2 we can observe the leftwards displacement of the overriding plate and the trench and the rightwards displacement of the subducting plate and ridge (where present); the deformation of the overriding plate; the change of the slab angle; the hydration of the mantle above the subducted oceanic plate; the generation of molten rocks in the mantle wedge; the development of molten plumes and waves along the subduction zone ( $c f$., red diapiric and wave-like structures forming atop the slab in Fig. 2a) (Gerya et al., 2004, 2006; Gorczyk et al., 2007a, b); and the isotherm displacement and the stability of subduction over the modelled time period. As can also be seen by comparing cases with and without a ridge, the influence of the ridge on the model development is rather minor and does not produce significant changes either in slab angle (Fig. 3) or in magma production in the mantle wedge (Fig. 4). In contrast, effects of the ridge on the topographic development (Fig. 5) are very distinct: (i) notable (by 20-40 km) rightward displacement of the trench ( $c f$., positions of black triangles for models with and without a ridge in Fig. 2) and (ii) creating a $2-3 \mathrm{~km}$ topographic high above the subducting ridge during the relatively shallow stages of ridge subduction (4-10 Myr, Fig. 5c). As soon as the ridge reaches asthenospheric depths, its topographic influence starts to decay and disappears after it moves $200-300 \mathrm{~km}$ landward from the trench. Both the trench displacement and topographic high in the continental part of the overriding plate are sustained for at least several million years after the ridge passes the trench (Fig. 5c). This is in contrast to the topography above the deforming accretionary prism where the topographic perturbation rapidly relaxes with time (Fig. 5c). The topography rising above the subducting ridge exceeds the original ridge height (Fig. 5c) due to additional uplift resulting from the overriding plate shortening. Additionally, ridge passage causes more erosive subduction resulting in a reduced size of the sedimentary complex (accretionary wedge) in the model with the ridge compared to the one without (Fig. 2c). Intense subduction erosion of the accretionary complex by the ridge passage

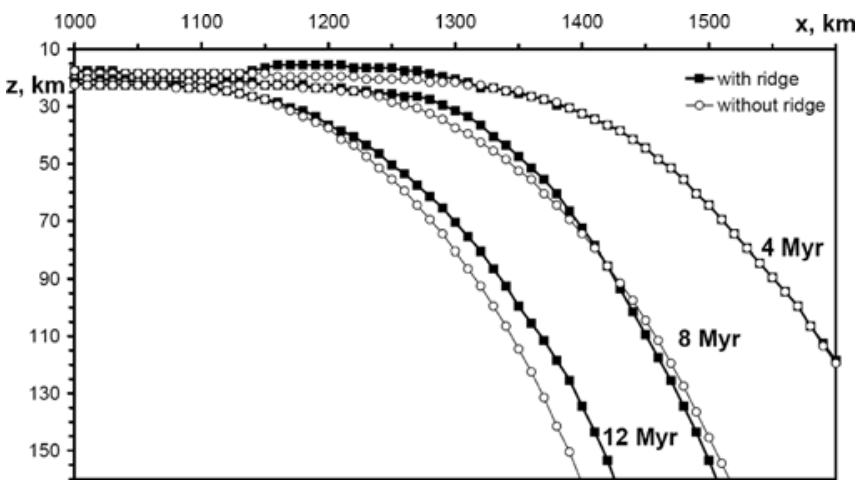

Fig. 3. Comparison of slab positions (upper boundary) for reference models with (solid squares) and without (open circles) a ridge (Fig. 2).
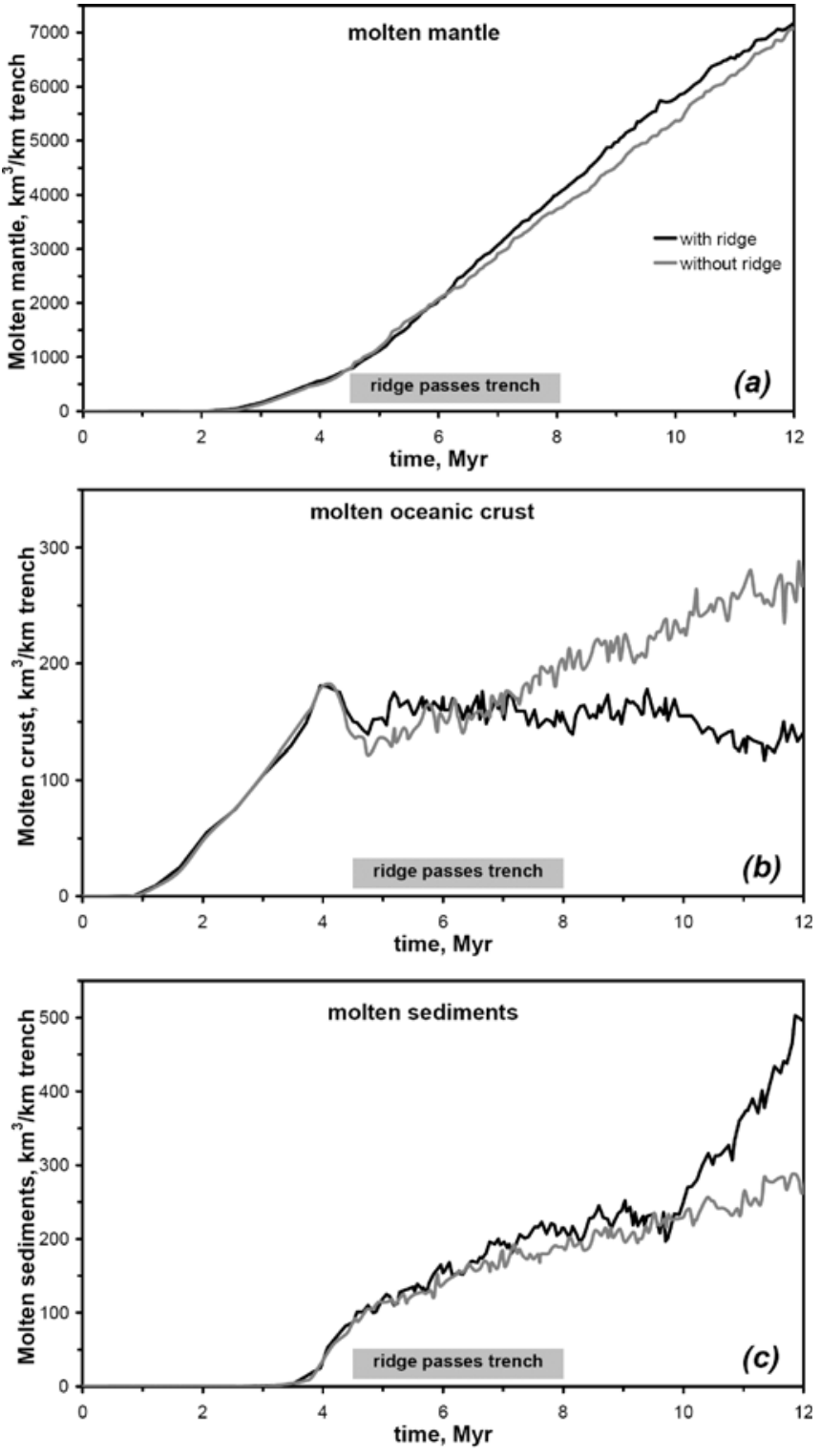

Fig. 4. Comparison of changes in the amount of partially molten mantle (a) oceanic crust (b) and sediments (c) for reference models with (black lines) and without (grey lines) a ridge (Fig. 2). Different amount of partially molten sediments for models with and without a ridge in (b) is mainly related to variations in entrainment of sediments by molten plumes rising from the slab (Fig. 2a) (Gerya et al., 2006).

may also partly explain the rapid relaxation of topographic perturbation in this region (Fig. 5c).

\subsection{Influences of slab density}

Figure 6 illustrates results of paired numerical experiments performed at a variable slab density. It should be pointed out that we explored a very broad range of lithospheric densities (from 3100 to $3400 \mathrm{~kg} / \mathrm{m}^{3}$ ) testing extreme variations in slab buoyancy e.g. due to the presence of a thick and long oceanic plateau and/or strong mantle lithosphere 


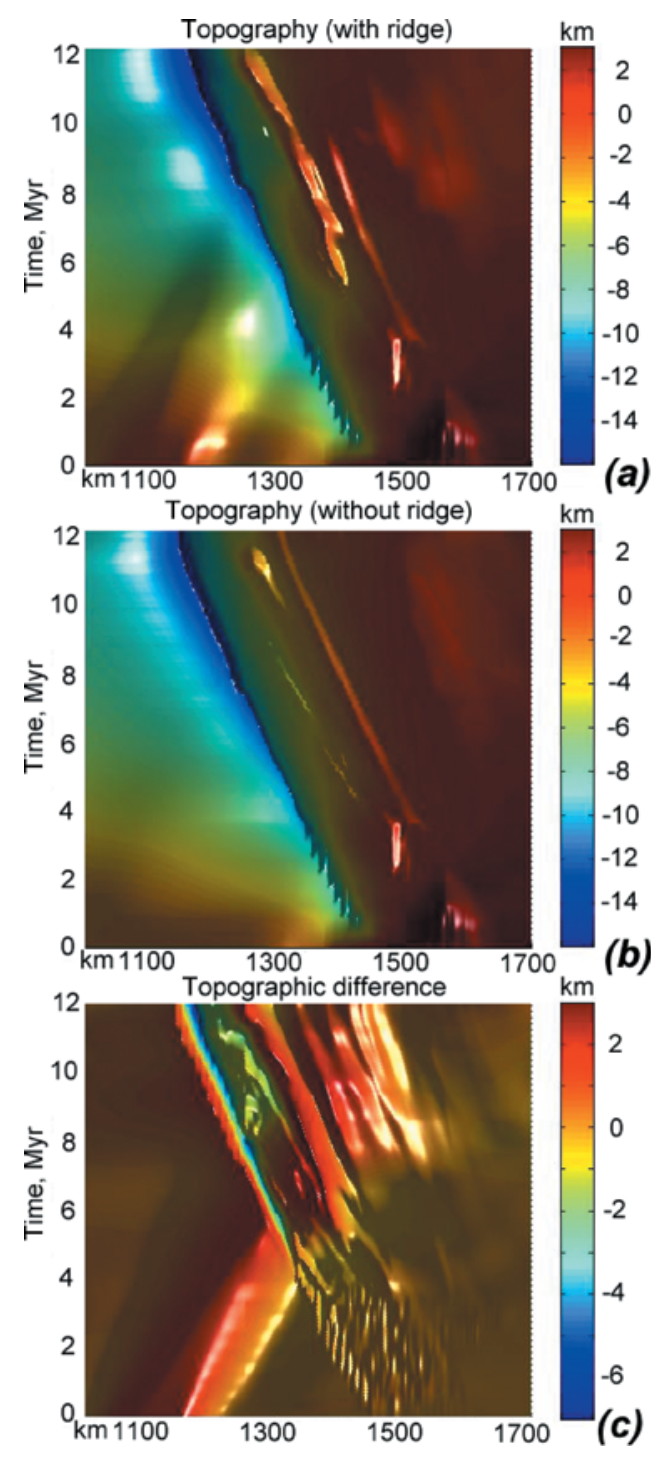

Fig. 5. Comparison of topographic evolution over time for reference models with (a) and without (b) a ridge (Fig. 2) and topographic difference between them (c). Top views on the lightened 3D surfaces are shown.

depletion (lowered slab density) or complete eclogitization of subducted oceanic crust (increased slab density). As in the reference models, the influence of the ridge on model development is rather minor at all slab densities (Fig. 6, 7, 8) and does not significantly affect either slab angles (Fig. 7) or magma production (Fig. 8). Slab flattening caused by a ridge (uplifting of $5-40 \mathrm{~km}$ ) is only seen for heavy slabs when the density contrast between the plate and the ridge is greatest (Fig. 7, slab density $=3300-3400$ $\mathrm{kg} / \mathrm{m}^{3}$ ). But the lower-density case has a flat slab with or without a ridge (Fig. 7, slab density $=3100 \mathrm{~kg} / \mathrm{m}^{3}$ ). Another important point to mention is that, irrespective of the presence/absence of a ridge, models with flat slabs (Fig. 6a, 8) always reveal strongly lowered volumes of partially molten rocks in the mantle (Fig. 7, 8; $3100 \mathrm{~kg} / \mathrm{m}^{3}$ ) compared to models with inclined slabs (Fig. 7, 8; 3200-3400 kg/m ${ }^{3}$ ). Topographic effects caused by a ridge are similar to those for the reference model and do not notably change with variations in slab density ( $c f$. ., Fig. 5c, 9). Indeed, topographic development for $3400 \mathrm{~kg} / \mathrm{m}^{3}$ case (Fig. 9c) is complicated by delamination of the dense slab from the overriding plate and rapid trench retreat associated with rapid intra-arc extension (Fig. 6c).

\subsection{Influences of plate velocity}

We tested both variations in total convergence rate and in individual plate velocities. Total convergence rate was varied from 4 to $10 \mathrm{~cm} / \mathrm{yr}$ at the constant $1: 1$ ratio between velocities of individual plates. As can be seen from Fig. 10a, 11a-b, both topographic development and slab dynamics scale linearly with the total amount of convergence for models with different convergence rates. In contrast, the volume of partially molten rocks (Fig. 12) is systematically greater for models with slower convergence rates at the same amount of convergence. This is mainly related to the adopted constant rate $(1 \mathrm{~cm} / \mathrm{yr})$ of fluid propagation from the slab, so that in the case of slow convergence rate the fluid has more time to hydrate the mantle wedge above the slab, which in turn increases hydrous melting. Also, slower slabs are generally warmer and are therefore subjected to more intense dehydration.

Individual plate velocities were varied at the constant convergence rate of $6 \mathrm{~cm} / \mathrm{yr}$. It should be pointed out that the reference frame in all our experiments is given by asthenospheric mantle whose lateral motion is limited by free slip conditions applied at two impermeable vertical model boundaries. Therefore plates are moving differently relatively to the underlying asthenospheric mantle in experiments with different prescribed plate velocities even if total convergence rate does not change. Variations in individual plate velocities notably affect the slab position in the mantle (Fig. 10b) and the dynamics of trench movement (Fig. 11c, d) but have a much decreased effect on magma production (Fig. 13).

In all studied cases with variable plate velocities, influences of the presence/absence of the ridge on the slab inclination and magmatic rock production are rather minor. Topographic effects related to the ridge passage are similar to those for the reference model and do not notably change with variations in plate velocities (cf., Fig. 5c, 11).

\section{Geological example}

We compared the results of our numerical experiments to the process of subduction of the Nazca Ridge whose approximate dimensions were chosen for this modelling exercise. Figure 14 presents the geodynamic situation along the western margin of S. America where subduction of the Nazca ridge takes place. To the west the Andean chain defines the boundary between the South American Plate and three oceanic plates. These plates are from north 

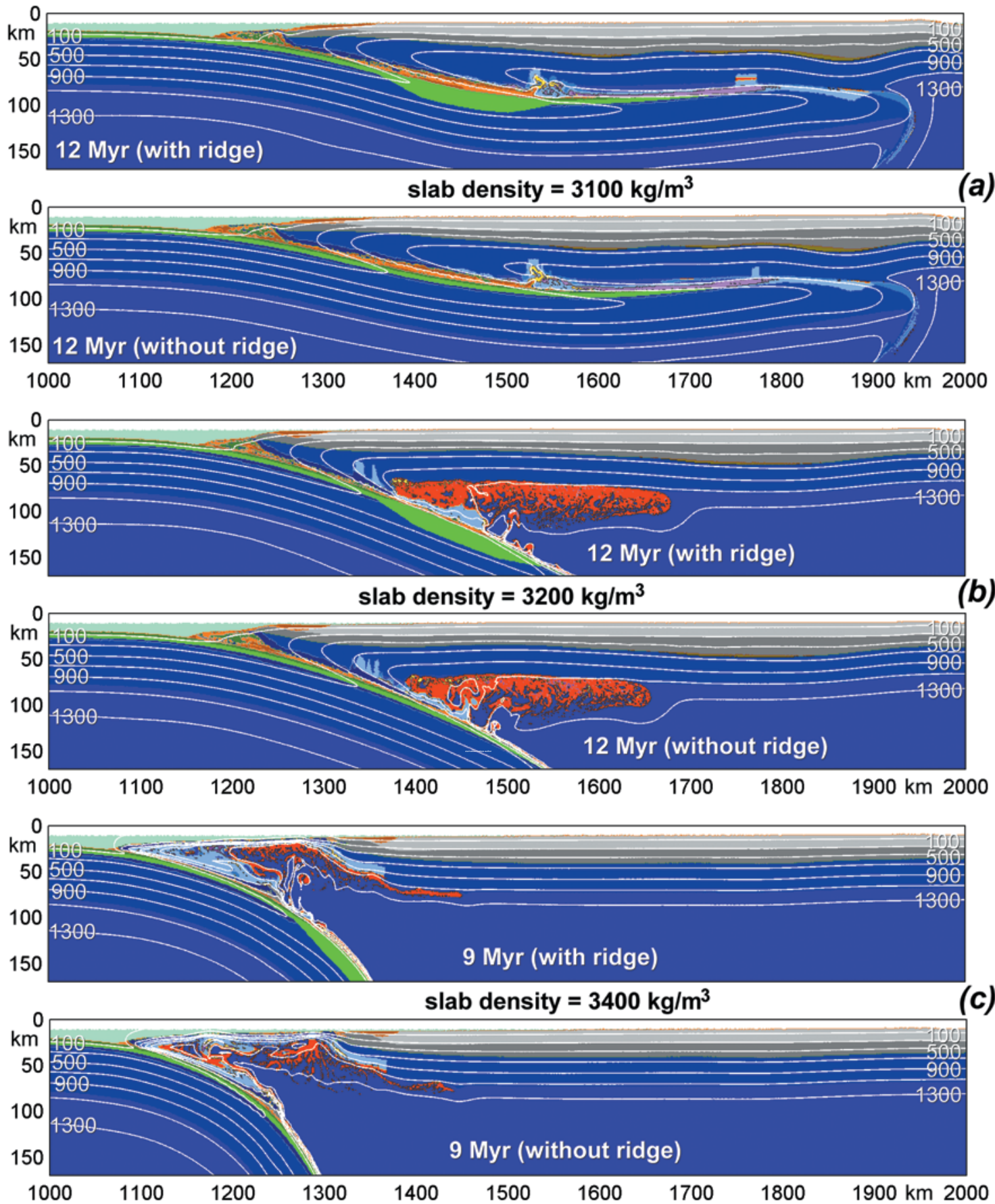

Fig. 6. Influence of slab density for development of numerical models with and without a ridge: (a) - slab density of $3100 \mathrm{~kg} / \mathrm{m}^{3}$ (models ria333100m and ria333100o in Table 2). (b) - slab density of $3200 \mathrm{~kg} / \mathrm{m}^{3}$ (models ria333200m and ria333200o in Table 2). (c) - slab density of $3400 \mathrm{~kg} / \mathrm{m}^{3}$ (models ria333400m and ria333400o in Table 2). Models in (a), (b), and (c) are shown at different time but for the same amount of subduction $(720 \mathrm{~km})$. Colour code is the same as in Fig. 2. White lines represent isotherms in ${ }^{\circ} \mathrm{C}$.

to south: the Cocos Plate, the Nazca Plate and the Antarctic Plate.

The Peruvian segment of the Andes (5-18 S), which has a longitudinal extent of approximately $2000 \mathrm{~km}$, follows a northwest to southeast trend. In general the Andes form a highly asymmetric topography with a steep western slope and a wide eastern side. On the oceanic side of the margin the Nazca Plate is migrating to the east-northeast at a rate of around $5 \mathrm{~cm} / \mathrm{yr}$ while the South American continent migrates westward at a rate of approximately $3 \mathrm{~cm} / \mathrm{yr}$ resulting in a convergence rate between the two plates of about $6.1 \mathrm{~cm} / \mathrm{yr}$. As a result the oceanic Nazca Plate is consumed along the deep sea trench from Colombia in the north down to southern Chile. The oceanic plate is of Eocene to early Oligocene age, approximately 50-30 Ma (Wipf, 2006; Wipf et al., 2008). The 


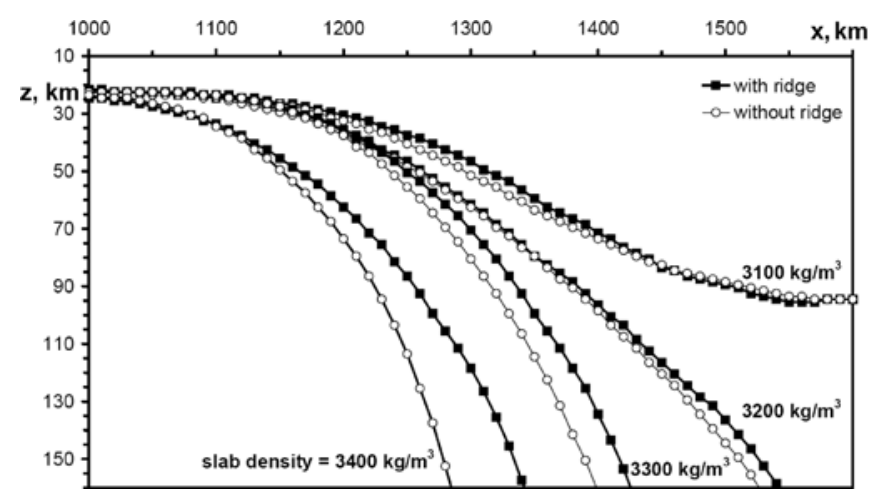

Fig. 7. Comparison of slab positions (upper boundary) for models with (solid squares) and without (open circles) a ridge in numerical experiments with variable slab density (Fig. 2,6).
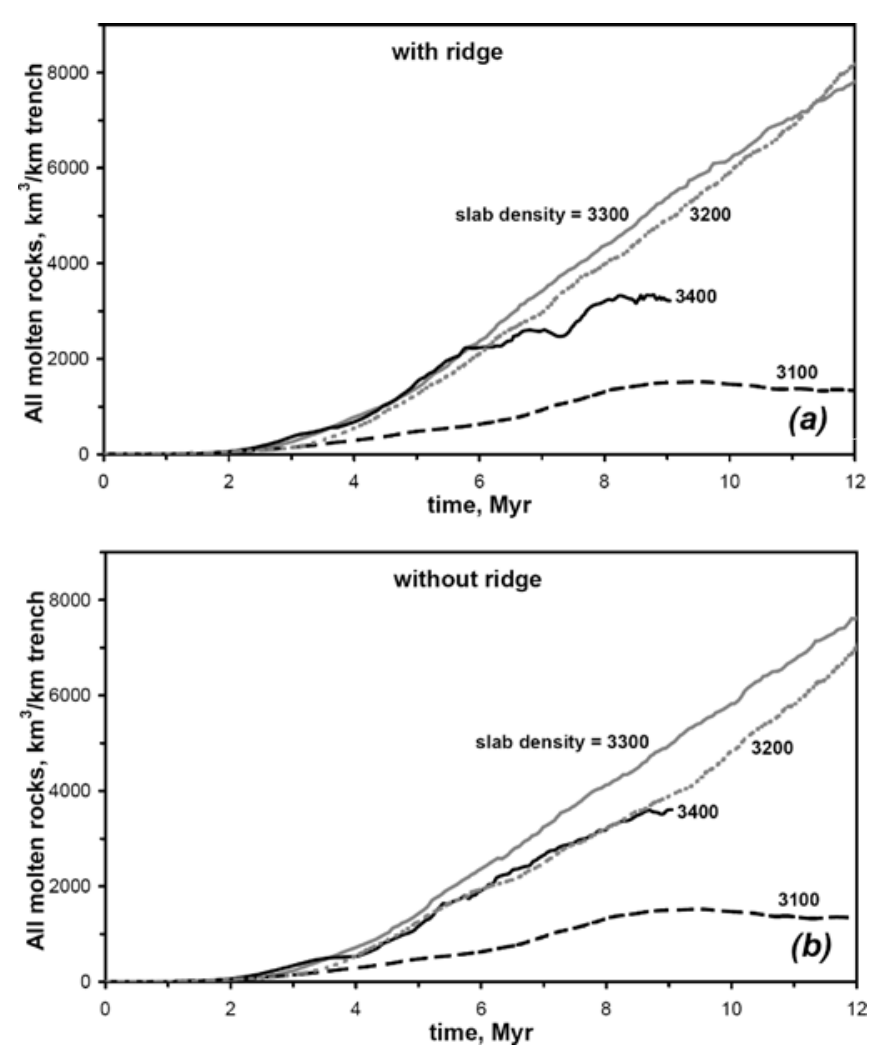

Fig. 8. Comparison of changes in the amount of partially molten rocks in the mantle wedge for models with (a) and without (b) a ridge in numerical experiments with variable slab density (Fig. 2,6).

$1.5 \mathrm{~km}$ high Nazca Ridge is carried on the Nazca plate and is currently being subducted at approximately $15^{\circ} \mathrm{S}$. Hampel (2002) suggested that the Nazca Ridge per se began subducting $11 \mathrm{Ma}$ ago at $11.2^{\circ} \mathrm{S}$ while Rosenbaum et al. (2005) determined this collision to have begun at $\sim 10^{\circ} \mathrm{S}$ as early as $15 \mathrm{Ma}$. This is earlier than the time frame of 10 and 12 Ma proposed for the subduction of the "Lost Inca Plateau" in northern Peru by Gutscher et al. (1999) (Fig. 14). However, regardless of the timing of events, it is clear from both the models and the geology

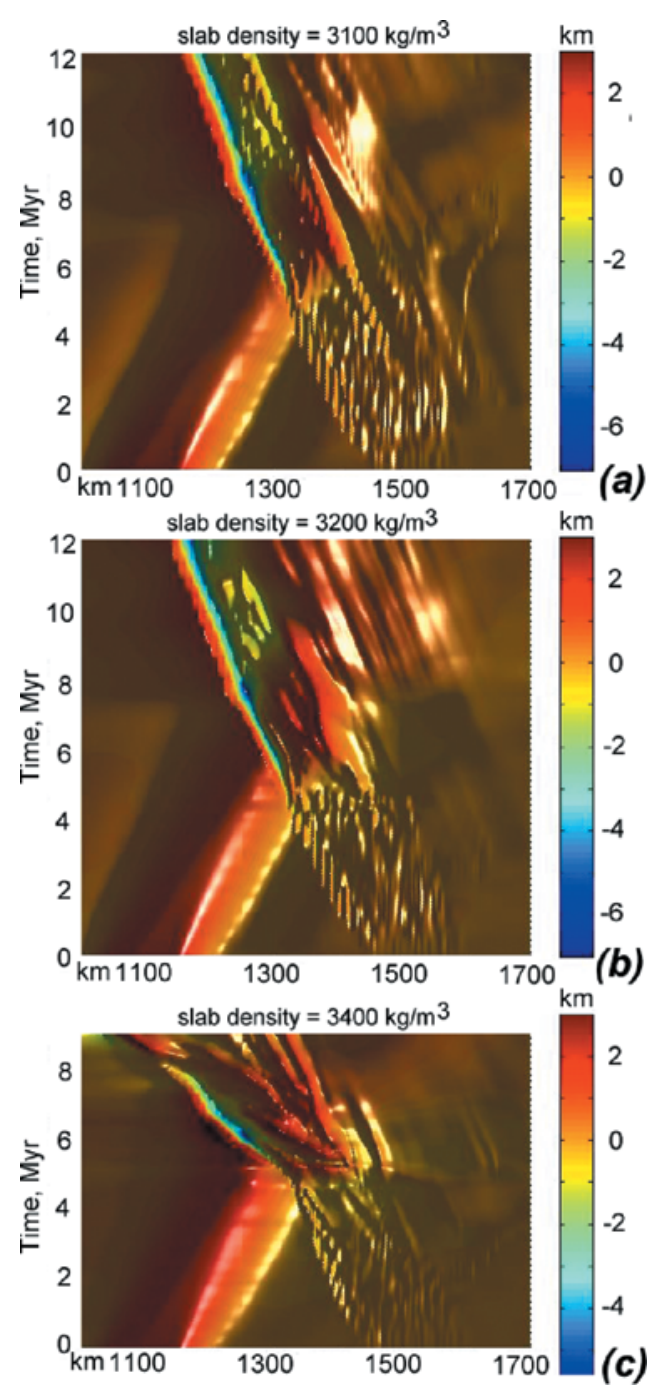

Fig. 9. Comparison of topographic difference for models with and without a ridge in numerical experiments with variable slab density (Fig. 6). Top views on the lightened 3D surfaces are shown.

that as the ridge migrates southwards it causes wave-like behaviour with various impacts at the region of contact resulting in various changes to the pre-existing characteristics, particularly the geomorphology, as described below:

Trench depth. In all our models the passage of the ridge across the trench results in 1-3 km higher topography above the ridge (Fig. 5c, 9, 11). In the area of the deep sea trench the uplift is at least $1500 \mathrm{~m}$ as the depth of the trench decreases from almost $6500 \mathrm{~m}$ south of the ridge to $5200 \mathrm{~m}$ over the leading edge and to $4800 \mathrm{~m}$ over the northern section of the ridge. Further northwards, in the lee of the ridge, the water depth increases again to 6000 and $6500 \mathrm{~m}$, supporting the relaxation as recognized in our models.

Flat subduction and volcanic gap. Trailing this collision zone northwards between $5^{\circ}$ and $14^{\circ} \mathrm{S}$ a $1500 \mathrm{~km}$ long segment of flat subduction $\left(<30^{\circ}\right)$ exists. Within this zone recent volcanism is almost absent in spite of active subduction. Only the Cordillera Blanca, located between 

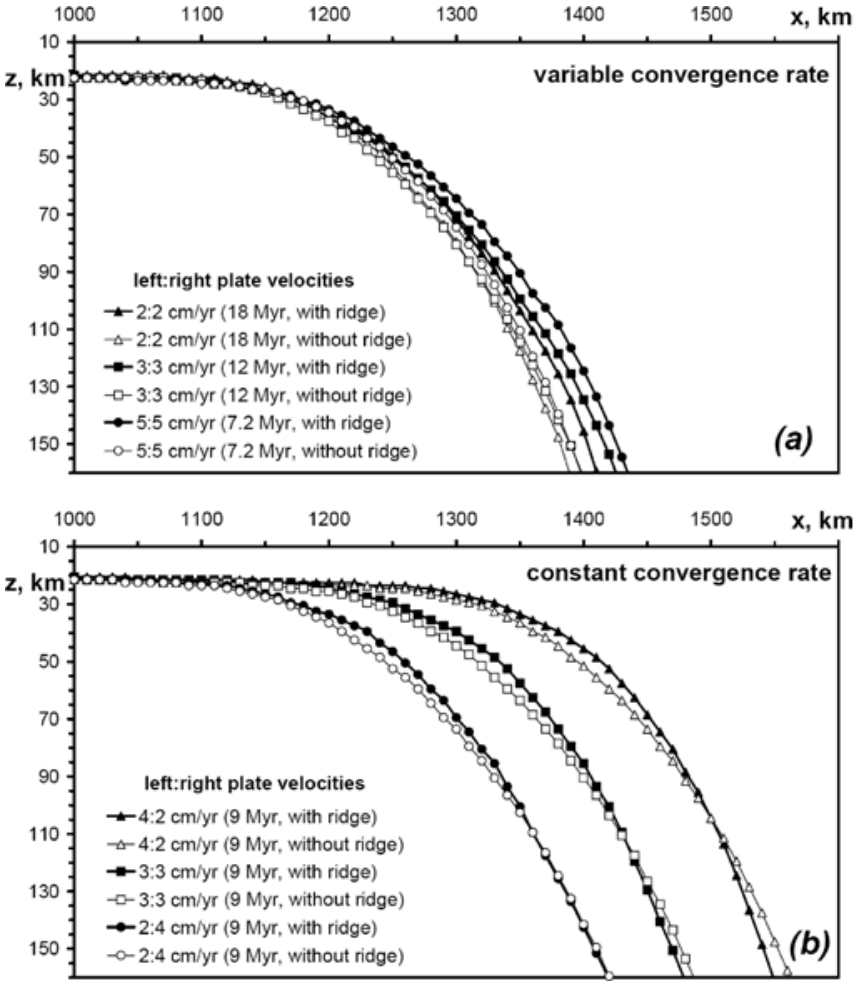

Fig. 10. Comparison of slab positions (upper boundary) for models with (solid squares) and without (open circles) a ridge in numerical experiments with variable convergence rate (a) and variable plate velocities (b).
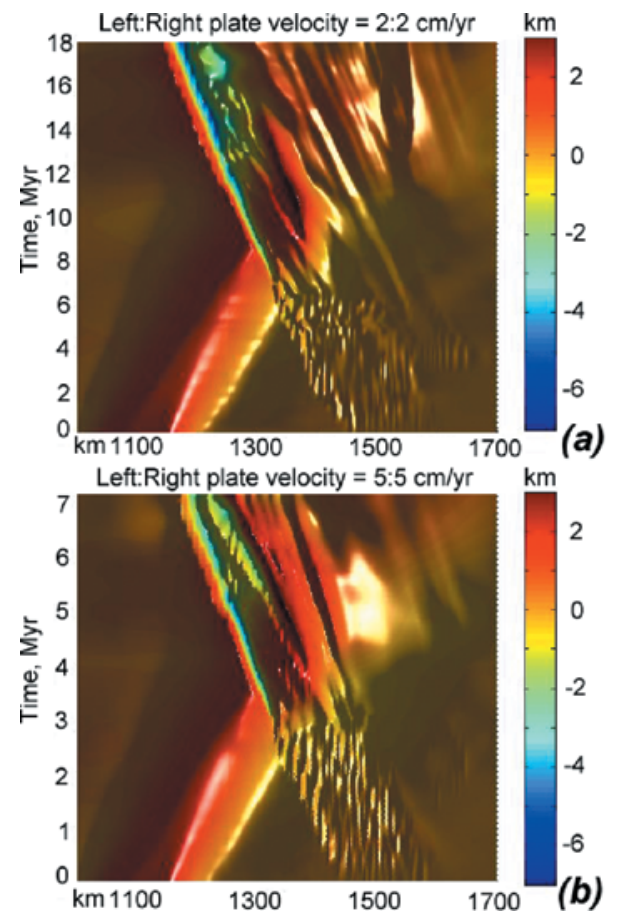
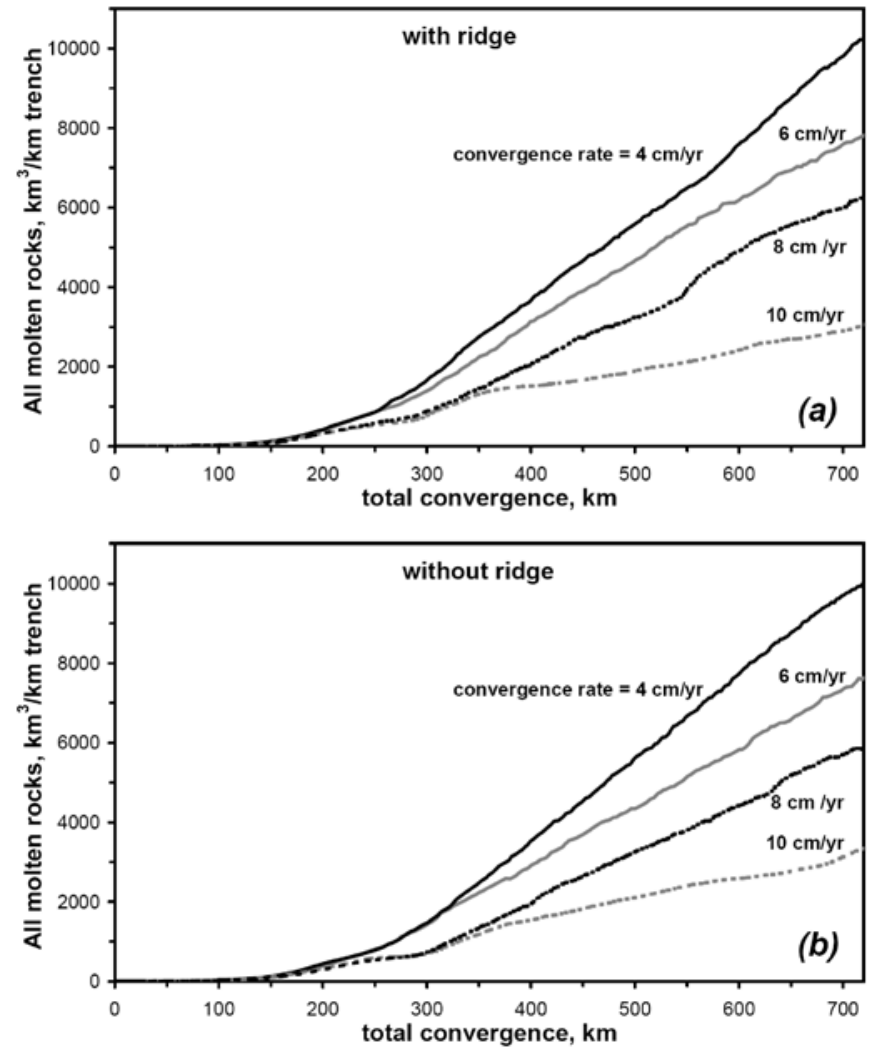

Fig. 12. Comparison of changes in the amount of partially molten rocks in the mantle wedge for models with (a) and without (b) a ridge in numerical experiments with variable convergence rate (at constant 1:1 left:right plate velocity ratio).

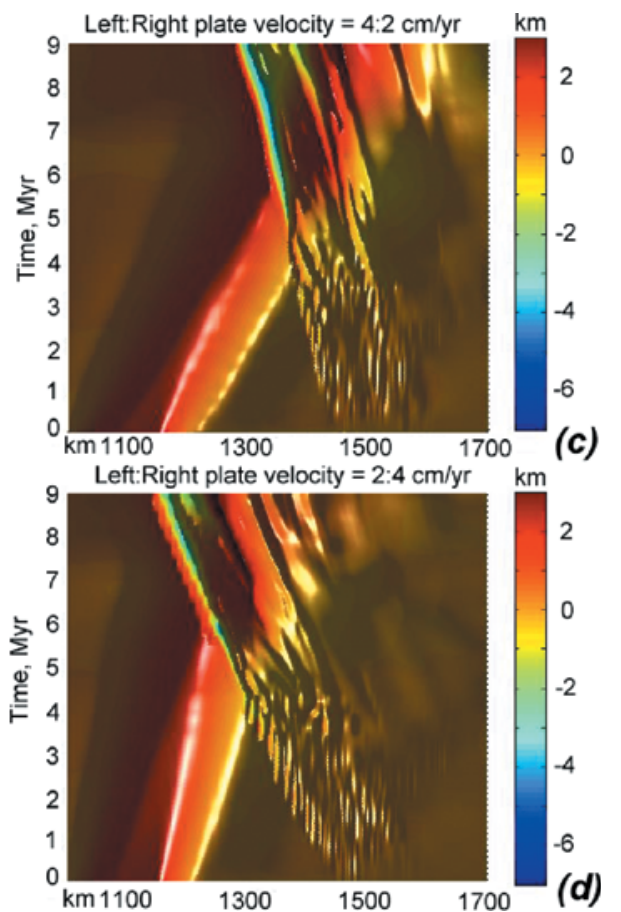

Fig. 11. Comparison of topographic difference for models with and without a ridge in numerical experiments with variable convergence rate (a), (b) and variable plate velocities (c), (d). (a) - Model ria223300 in Table 2. (b) - Model ria553300 in Table 2. (c) - Model ria423300 in Table 2. (d) - Model ria243300 in Table 2. Top views on the lightened 3D surfaces are shown. 

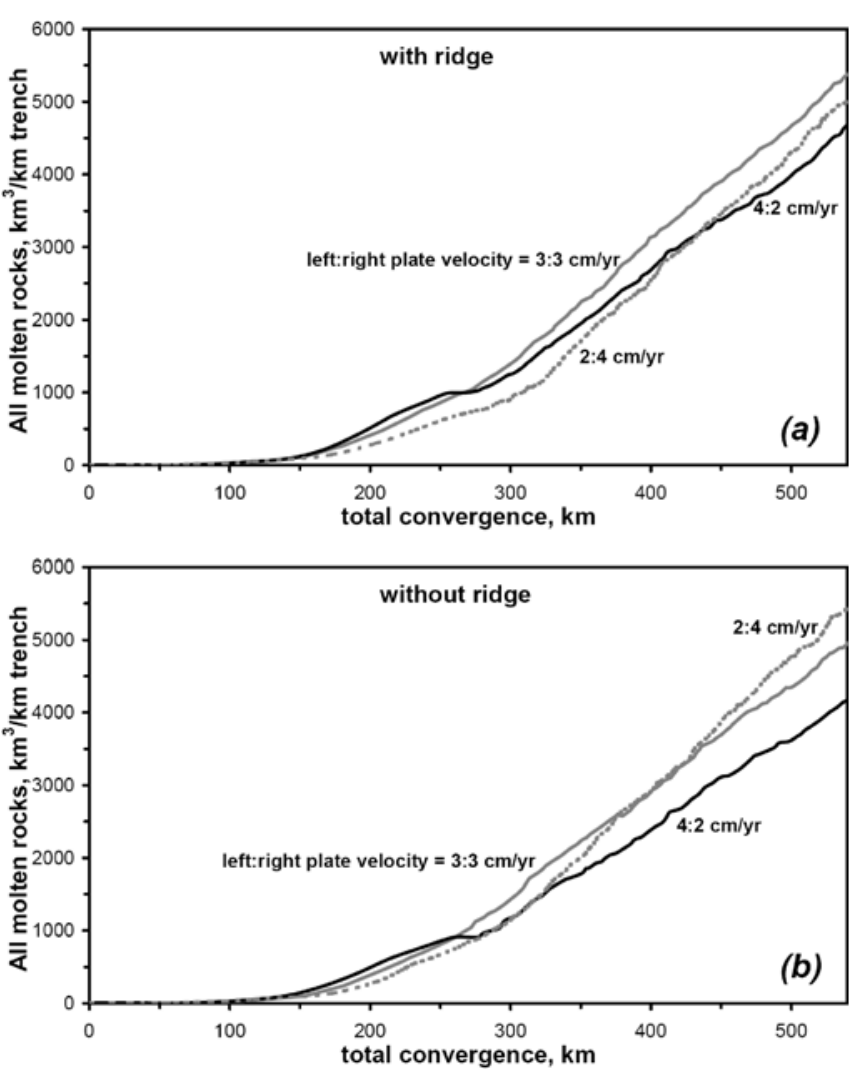

Fig. 13. Comparison of changes in the amount of partially molten rocks in the mantle wedge for models with (a) and without (b) a ridge in numerical experiments with variable individual plate velocities (at constant $6 \mathrm{~cm} / \mathrm{yr}$ convergence rate).

$9^{\circ}$ and $11^{\circ} \mathrm{S}$, contains a record of Neogene magmatic activity. Our numerical models confirm that such flat subduction does indeed result in significant lowering of the amount of molten rocks forming above the slab (Fig. 6a, 8). This is obviously related to the absence of a hot mantle wedge above the flat slabs (Fig. 6a) and may cause gaps in volcanic activity for the episodes of slab flattening. This observation is irrespective of the physical origin of this process which may not necessarily be related to the ridge subduction itself, as evidenced from our models and those of others (e.g., van Hunen et al., 2004). Our models suggest that the Nazca ridge influence on slab flattening is actually quite minor unless the slab is in a near critical (i.e., transient from inclined to flat) state when a relatively small local addition of positive slab buoyancy from the subducted moderate-sized Nazca Ridge may trigger slab flattening.

Erosional subduction. The numerical modelling results suggest enhanced erosive subduction caused by the ridge passage ( $c f$., a reduced size of sediments in the accretionary wedge in the model with ridge, compared to that without in Fig. 2c). A similar situation is evidenced in the collision zone of the obliquely subducting Nazca Ridge where the Peruvian forearc is characterized by enhanced tectonic erosion (Clift et al., 2003; Hampel et al., 2004b). Evidence for this includes such phenomena as the recognition that the thin sediment layer on the ridge is completely

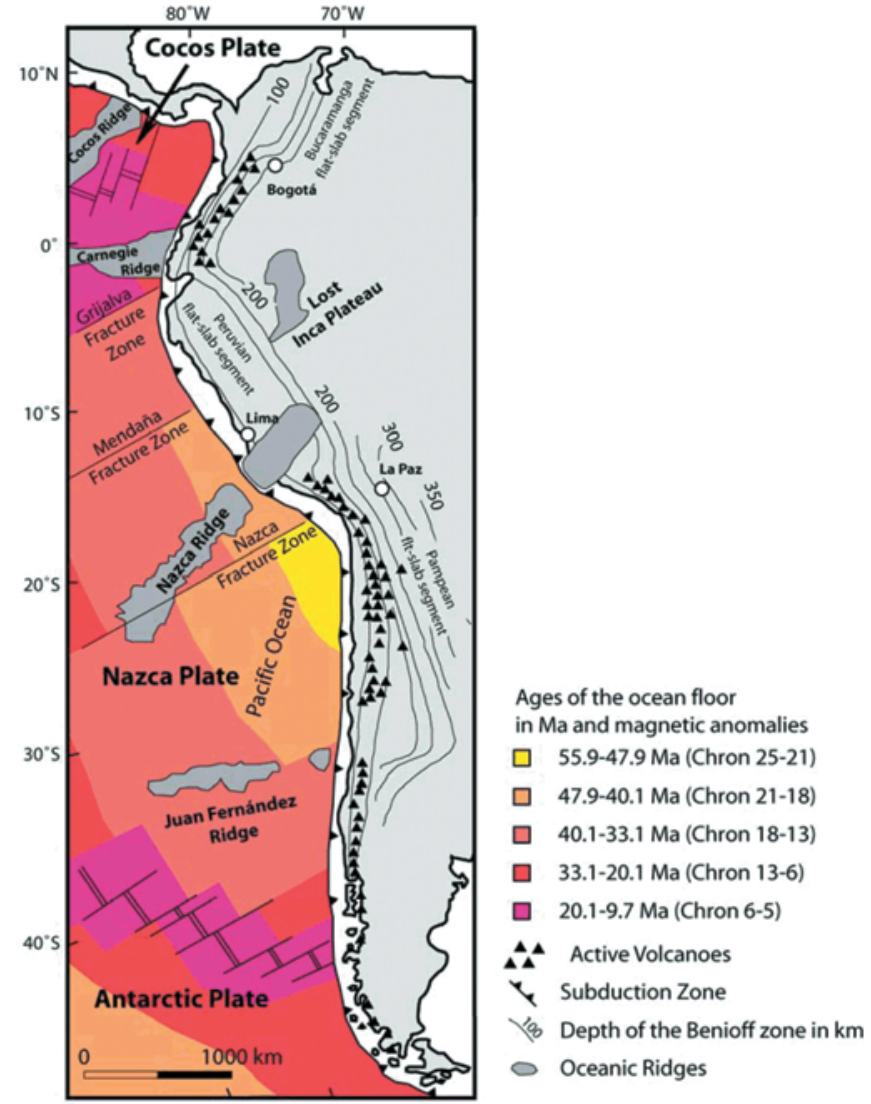

Fig. 14. Plate setting of the west coast of South America. Plate boundaries, location of active volcanoes, and depth of the WadatiBenioff plane after Ramos \& Aleman (2000); location of aseismic ridges including the "Lost Inca Plateau" after Gutscher et al. (1999, 2000), age of the oceanic plate after Muller et al. (1997) (after Wipf, 2006).

subducted, that the lower continental slope is steep, dipping at $\sim 9^{\circ}$, and the continental wedge has a high taper of $18^{\circ}$. The passage of the Nazca Ridge southwards along the continental margin induces a time-limited phase of enhanced tectonic erosion (Hampel et al., 2004b) superposed on the long-term erosion regime.

Intense subduction erosion of the accretionary complex by the ridge passage may also partly explain relaxation of topography (compared to models without ridge) in this region after the ridge passage, as evidenced by topography difference plots (Fig. 5c, 9a, b, 11a, b). Such a scenario is also supported by geological evidence whereby Hampel et al. (2004b) noted from the sediments of ODP leg112 that forearc uplift was followed by subsidence as the ridge moved southwards.

Surface uplift. Our modelled data predicts, regardless of initial parameters, a $2-3 \mathrm{~km}$ topographic high above the subducting ridge during the relatively shallow stages of ridge subduction (4-10 Myr, e.g., Fig. 5c). Further, the topography rising above the subducting ridge exceeds the original ridge height (see Fig. 5c) and the topographic increase in height decreases to zero some $250 \mathrm{~km}$ from the trench. Both the topographic high in the continental 
part of the overriding plate and trench displacement are sustained for at least several million years after the ridge passes the trench (Fig. 5c).

As mentioned above, surface uplift of the trench is reflected in trench depth. Uplift decreases away from the trench in the models - a phenomenon that is evidenced through the coastal margin uplifted marine terraces. The observed altitudes of the terraces over the Nazca Ridge are 900-1000 m. However, this value has to be considered as a minimum as older terraces may have been removed by the erosion. Wipf et al. (2008) estimated erosion rates on the ridge and just to the north to range from 0.06 to $4 \mathrm{~mm} / \mathrm{yr}$. Based on models by Hsu (1992) and Hampel et al. (2004a) an uplift of $1200 \mathrm{~m}$ would be expected. The altitude is higher in the central south towards the leading edge of the ridge. Further inland, surface uplift decreases and disappears some $50 \mathrm{~km}$ from the coast (Hsu, 1992; Machare \& Ortlieb, 1992; Hagen \& Moberly, 1994; Li \& Clark, 1994; Hampel et al., 2004a). Our data predicts that, as soon as the ridge reaches asthenospheric depths, its topographic influence starts to decay and disappears after it moves 200-300 km landward from the trench. Although lowtemperature thermochronology does not measure uplift, Wipf et al. (2008) were able to ascertain that beyond some tens of kilometres inland no effect of the subducting ridge is observable. Both this data and that of our new modelling are contradictory to the findings of Espurt et al. (2007) who reportedly identified an impact of the Nazca ridge in the Amazonian Foreland.

Further, the modelled data presented here also predict that the continental topography will be sustained for several million years after subduction of the ridge and will then relax. It is estimated to take $4 \mathrm{Myr}$ for the ridge to move from point to point southwards. The reduction in height of the Coastal Cordillera from south $(1800 \mathrm{~m})$ to north $(900 \mathrm{~m})$, at the present position of the ridge, may be due to several parameters including time of exposure to erosion but also to such a relaxation. Northwards from the present northern limit of the ridge, Macharé \& Ortlieb (1992) recognized that terraces are absent, providing supporting evidence that the coast subsides after the ridge has passed. Additional verification is given to the north of the current ridge position, by the adjustment and associated rerouting of river systems (Wipf et al., 2008) as well as the very obvious indentation of the coastline north of the ridge. Northwards again, at $11.5 \mathrm{~S}$ where the ridge was positioned some $9.5 \mathrm{Myr}$ ago, evidence for subsidence is also seen through ODP leg 112 cores, where there is a Late Miocene change from shelf to deeper water facies at this time (Hampel, 2002). The change coincides with the predicted passage of the ridge.

\section{Discussion and conclusions}

Numerical experiments modelling subduction of a moderatesize aseismic ridge suggest that this process does not result in major changes of slab dynamics and magmatic activity compared to normal subduction. This conclusion partly agrees with the previous numerical and analogue modelling studies, demonstrating the complexity of slab response to such ridge subduction. These results confirm the work of Martinod et al. (2005) who demonstrated that the rigidity of the plate forces the ridge to subduct with the dense oceanic lithosphere hence precluding significant slab flattening. Also the numerical modelling of van Hunen et al. (2000, 2004) suggested that the maximum yield stress in the slab must be limited to about 600 $\mathrm{MPa}$ to allow for the necessary bending towards the horizontal and that additional mechanisms, such as active overthrusting by an overriding continental plate, are needed to explain the flat slab segments. This compares well with minor changes in slab position caused by the subducted moderate-sized ridge in our numerical experiments (Fig. 3, 7, 10). One can assume, therefore, that in cases when slab flattening is observed in nature after the moderate-size ridge passage (as in the case of the Nazca Ridge) the slab itself must rather be in a nearly critical (transient) state when the local addition of positive buoyancy may trigger slab flattening. Subducting ridges may serve as indicators of transient slab states.

Another important result from our study is the quantification of strongly decreased magma production in the case of flat slabs (Fig. 6a, 8). This favourably compares with gaps in recent active volcanism at low-angle subduction below Peru, Central Chile and at the Nankai trough near Japan apparently associated with the subduction of the Nazca Ridge, Juan Fernandez seamount chain and Palau-Kyushu Ridge, respectively (Cross \& Pilger, 1982; McGeary et al., 1985). On the other hand the decrease of magma production does not directly depend on the mechanism responsible for the triggering of slab flattening (van Hunen et al., 2000, 2004) but is related to the absence of a hot mantle wedge above flat slabs (Fig. 6a).

Finally we document very distinct stable effects always associated with the ridge subduction such as increase in local topography, enhancement of subduction erosion and landward trench displacement. Surface uplift may exceed the original ridge height due to additional uplift resulting from the overriding plate shortening which is in agreement with conclusions made by Espurt et al. (2008). Topographic changes in the accretionary wedge domain are transient and have a tendency to relax after the ridge passes the trench, as seen also on the Peruvian margin. In contrast topographic highs created in the continental portion of the overriding plate relax more slowly and may be sustained for several millions of year after the ridge subduction (Fig. 5, 9, 11).

Acknowledgements: Constructive reviews by J. van Hunen and C. Faccenna are greatly appreciated. This work was supported by ETH Research Grants TH-12/05-3, TH0807-3, SNF Research Grant 200021-113672/1, 200021$116381 / 1$, the RF President Programme "Leading Scientific School of Russia" (Grant \#1949.2008.5) to TVG. 


\section{References}

Clauser, C. \& Huenges, E. (1995): Thermal conductivity of rocks and minerals. in "Rock physics and phase relations", T.J. Ahrens, ed. Am. Geophys. Union, Washington DC, USA, 105-126.

Clift, P.D., Pecher, I., Kukowski, N., Hampel, A. (2003): Tectonic erosion of the Peruvian forearc, Lima Basin, by subduction and Nazca Ridge collision. Tectonics, 22, 1023-1043.

Cross, T.A. \& Pilger Jr., R.H. (1982): Controls of subduction geometry, location of magmatic arcs, and tectonics of arc and back-arc regions. Geol. Soc. Am. Bull., 93, 545-562.

Espurt, N., Baby, P., Brusset, S., Roddaz, M., Hermoza, W., Regard, V., Antoine, P.-O., Salas-Gismondi. R., Bolanos, R. (2007): How does the Nazca Ridge subduction influence the modern Amazonian foreland basin? Geology, 35, 515-518.

Espurt, N., Funiciello, F., Martinod, J., Guillaume, B., Regard, V., Faccenna, C., Brusset, S. (2008): Flat subduction dynamics and deformation of the South American plate: Insights from analogue modeling. Tectonics, 27, Art. No TC3011.

Faccenda, M., Burlini, L., Gerya, T.V., Mainprice, D. (2008): Faultinduced seismic anisotropy by hydration in subducting oceanic plates. Nature, 455, 1097-1101.

Gerya, T.V. \& Burg, J.-P. (2007): Intrusion of ultramafic magmatic bodies into the continental crust: Numerical simulation. Phys. Earth Planet. In., 160, 124-142.

Gerya, T.V. \& Stoeckhert, B. (2006): 2-D numerical modeling of tectonic and metamorphic histories at active continental margins. Int. J. Earth Sci., 95, 250-274.

Gerya, T.V. \& Yuen, D.A. (2003): Characteristics-based marker-incell method with conservative finite-differences schemes for modeling geological flows with strongly variable transport properties. Phys. Earth Planet. In., 140, 293-318.

Gerya, T.V., Yuen, D.A., Sevre, E.O.D. (2004): Dynamical causes for incipient magma chambers above slabs. Geology, 32, 89-92.

Gerya, T.V., Connolly, J.A.D., Yuen, D.A., Gorczyk, W., Capel, A.M. (2006): Seismic implications of mantle wedge plumes. Phys. Earth Planet. In., 156, 59-74.

Gorczyk, W., Willner, A.P., Gerya, T.V., Connolly, J.A.D., Burg, J.-P. (2007a): Physical controls of magmatic productivity at Pacific-type convergent margins: new insights from numerical modeling. Phys. Earth Planet. In., 163, 209-232.

Gorczyk, W., Gerya, T.V., Connolly, J.A.D., Yuen, D.A. (2007b): Growth and mixing dynamics of mantle wedge plumes. Geology, 35, 587-590.

Gutscher, M.A., Olivet, J.L., Aslanian, D., Eissen, J.P., Maury, R. (1999): The "Lost Inca Plateau": cause of flat subduction beneath Peru? Earth Planet. Sci. Lett., 171, 335-341.

Gutscher, M.A., Spakman, W., Bijwaard, H., Engdahl, E.R. (2000): Geodynamics of flat subduction: seismicity and tomographic constraints from the Andean margin. Tectonics, 19, 814-833.

Hagen, R.A. \& Moberly, R. (1994): Tectonic effects of a subducting aseismic ridge: the subduction of the Nazca Ridge at the Peru Trench. Mar. Geophys. Res., 16, 145-161.

Hampel, A. (2002): The migration history of the Nazca Ridge along the Peruvian active margin: A re-evaluation. Earth Planet. Sci. Lett., 203, 665-679.

Hampel, A., Adam, J., Kukowski, N. (2004a): Response of the tectonically erosive south Peruvian forearc to subduction of the Nazca Ridge: analysis of three-dimensional analogue experiments. Tectonics, 23, Art. No TC5003.
Hampel, A., Kukowski, N., Bialas, J., Huebscher, C., Heinbockel, R. (2004b): Ridge subduction at an erosive margin: the collision zone of the Nazca Ridge in southern Peru. J. Geophys. Res., 109, Art. No B02101.

Hsu, J.T. (1992): Quaternary uplift of the Peruvian coast related to the subduction of the Nazca Ridge: 13.5 to 15.6 degrees south latitude. Quat. Int., 15/16, 87-97.

Li, C. \& Clark, A.L. (1994): Tectonic effects of the subducting Nazca Ridge on the Southern Peru continental margin. Mar. Petrol. Geol., 11, 575-586.

Macharé, J. \& Ortlieb, L. (1992): Plio-Quaternary vertical motions and the subduction of the Nazca Ridge, central coast of Peru. Tectonophysics, 205, 97-108.

Martinod, J., Funiciello, F., Faccenna, C., Labanieh, S., Regard, V. (2005): Dynamical effects of subducting ridges: insights from 3-D laboratory models. Geophys. J. Int., 163, 1137-1150.

McGeary, S., Nur, A., Ben-Avraham, Z. (1985): Spacial gaps in arc volcanism: the effect of collision or subduction of oceanic plateaus. Tectonophysics, 119, 195-221.

Muller, R.D., Roest, W.R., Royer, J.Y., Gahagan, L.M., Sclater, J.G. (1997): Digital isochrons of the world's ocean floor. J. Geophys. Res., 102, 3211-3214.

Ramos, V. \& Aleman, A. (2000): Tectonic evolution of the andes. in "Tectonic evolution of South America", U.G. Cordani, E.J. Milani, A. Thomaz Filho, D.A. Campos, eds. In-Folo Producao Editorial Grafica e Programacao Visual., Rio de Janeiro, Brazil, 635-685.

Ranalli, G. (1995): Rheology of the earth. Chapman \& Hall, London, UK, 413 p.

Regenauer-Lieb, K., Yuen, D.A., Branlund, J. (2001): The initiation of subduction: Criticality by addition of water? Science, 294, 578-580.

Rosenbaum, G., Giles, D., Saxon, M., Betts, P.G., Weinberg, R.F., Duboz, C. (2008): Subduction of the Nazca Ridge and the Inca Plateau: Insights into the formation of ore deposits in Peru. Earth Planet. Sci. Lett., 239, 18-32.

Rupke, L.H., Morgan, J.P., Hort, M., Connolly, J.A.D. (2004): Serpentine and the subduction zone water cycle. Earth Planet. Sci. Lett., 223, 17-34.

Sobolev, S.V. \& Babeyko, A.Y. (2005): What drives orogeny in the Andes? Geology, 33, 617-620.

Turcotte, D. L. \& Schubert, G. (2002): Geodynamics. Cambridge University Press, Cambridge, UK, $456 \mathrm{p}$.

Van Hunen, J., van den Berg, A.P., Vlaar, N.J. (2000): A thermomechanical model of horizontal subduction below an overriding plate. Earth Planet Sci. Lett., 182, 157-169.

Van Hunen, J., van den Berg, A.P., Vlaar, N.J. (2002): On the role of subducting oceanic plateaus in the development of shallow flat subduction. Tectonophysics, 352, 317-333.

Van Hunen, J., van den Berg, A.P., Vlaar, N.J. (2004): Various mechanisms to induce shallow flat subduction: a numerical parameter study. Phys. Earth Planet. In., 46, 179-194.

Wipf, M.A. (2006): Evolution of the Western Cordillera and coastal margin of Peru: evidence from low-temperature thermochronology and geomorphology. Swiss Federal Institute of Technology (ETH-Zürich), Zurich, Switzerland, Diss. No. 16383, 152 p.

Wipf, M., Zeilinger, G., Seward, D., Schlunegger, F. (2008): Focused subaerial erosion during ridge subduction: impact on the geomorphology in south-central Peru. Terra Nova, 20, 1-10.

Received 17 October 2008

Modified version received 11 December 2008

Accepted 22 January 2009 